\title{
The Effect of Individual and Group Jump Rope Games on Physical Fittnes and Motivation
}

\author{
Moh. Yusroni ${ }^{1}$, Abdul Rachman Syam T ${ }^{2}$, Amrozi Khamidi ${ }^{3}$ \\ ${ }^{1,2,3}$ Magister of Sport Education, Universitas Negeri Surabaya, Surabaya, Indonesia \\ myusronispdmpd@gmail.com
}

\begin{abstract}
This study aims to examine the effect of indifdual jump rope games and grouop jump rope on physical fitness and student motivation on futsal extracurricular students in MTs NU Berbek Waru Sidoarjo. This Study uses a quantitative approach to quasy expereriment research and the design ued is matching only design. The subjects of this study were 33 students who will be pretested to determine the division of groups. 11 students as the experimental group I were given the treatment of jump rope games individually and thefollowing 11 students as the experimental group II were reated as a group of jump rope games and the remeaning 11 studentswere made as a control group. Data collection methods in this study used two research instruments, namely the TKJI test to measure physical fitness scores and the motivation levels. Data werw analyzed with descriptive statistics using the SPSS 22.0 program. Based on the data obtained it can be concluded that there was a more significant increase in the two experimental groups compared to the control group. Physical fitness in all three groups experienced an increase, nmely by $6 \%$ in group I, 9\% in gropu II and $2 \%$ in group III. Student motivation has increased by $3 \%$ while in group III student motivation has descread by $1 \%$. The result of the study have proven that individual jump rope games and jump rope games in groups can improve the level of physicl fitness and motivation of students in following futsal extracurricular
\end{abstract}

Keywords: Individual jump rope; group jump rope; physical fitness; motivation.

\section{Introduction}

Sports and Health Physical Education is an education that can be carried out by doing physical sports activities, which aim to maintain and improve physical fitness, in which there are various aspects which include: speed, agility, strength and endurance. Physical Education is an important element in the growth and development of each individual human being. Physical education is useful for developing the skills, knowledge, values and attitudes needed to build and enjoy an active and healthy lifestyle, as well as building student confidence and competence in facing challenges both as individuals and as groups or teams through various learning activities (World Health Organization, 2002. p. 329).

$\mathrm{Ne}$ of the goals of physical education is to improve physical fitness, thinking skills, motor skills, reasoning skills, social skills, emotional stability, moral actions and healthy lifestyle

(Bastik, C. 2012). Improvement in physical fitness can be done by playing, according to Vameghi et al (2013), that play activities or games and physical activities are very closely related and cannot be separated in the lives of school-age children, if managed and carried out well will be able to affect physical development the child. Therefore good physical education should be able to prioritize the concept of play. Traditional Games are games that contain cultural values or elements of a particular region. According to Rouhi (2017) explains that, playing traditional games can maintain physical health, improve spiritual and mental conditions, and develop cultural values. Almost in every region in the world in general and in Indonesia in particular, has a traditional game in accordance with the customs and customs of 
the area. Some traditional games in Indonesia are very well known and are often played outside of their home regions, this is because the rules of the game are easy to understand and how to play that are easy and easy to understand, for example: Jumping Ropes and Fortbentengan.

Physical fitness is the ability of a person to do daily work without excessive fatigue and still have reserves of energy to enjoy his free time well (Physical Education Sport and Health, 2014, p. 177). Physical fitness is a physical aspect of overall fitness. Physical fitness can be called an indicator to determine a person's level of health (Okura, T. Et all, 2013). This was confirmed by Sulistyarto \& Ashadi (2013), physical fitness is the ability of a person to be able to carry out their duties and work or routine every day accompanied by excellent physical condition. In connection with physical fitness, there are several factors that need to be known and considered. Physical activity is very important for children's social life, because physical activity affects the motor development of school-age children (Ericsson, 2014). These factors are considered to affect the level of physical fitness of a person according to Sulistyarto \& Ashadi (2013).

Motivation is a desire that arises from within a person to do something that aims to achieve a certain goal. While motivation to learn is the desire of someone to be able to understand and understand something that they have not yet understood or not yet understood. As according to Djali (2014, p. 101) states that, "motivation is a psychological or mental condition that is in a human being that encourages people to carry out an activity with a specific purpose".

According to Mc. Donald in Sardiman (2006, p. 71) states that, "motivation is a change in energy that occurs in humans that begins with the emergence of a response to a particular goal". Meanwhile, according to Mylsidayu (2014, p. 56) states that, "motivation is a very large impulse or desire that arises from within humans to take an action in accordance with the desired goals and directions. In the world of education motivation is a very important part. This is as stated by Tatjana, et al (2014) that student motivation is recognized as the main factor determining student involvement in the education process. Furthermore according to Ramli $(2014$, p. 723 ) that motivation is a complex part of human psychology and behavior that affects these individuals to spend their time, how much energy they use in carrying out any task, how they think or overcome it and how long they or the individual will survive. So motivation to learn is a psychological condition that encourages students to learn in earnest, which in turn can form practical and systematic ways of student learning with full concentration.

According to Hamalik (2005, p. 171) states that, "the purpose of motivation is something that wants to be achieved from a behavior that if it can be achieved will make the person feel satisfied, happy and proud. An objective of a motivation can also determine the strength of the motivation itself (Hamalik, p. 171). According to Sudirman (2006, p. 83) states that there are two motivations, namely: "Intrinsic Motivation and Extrinsic Motivation" .a. Intrinsic motivation is motivation that arises or arises from within oneself. b. Extrinsic motivation is motivation that arises or arises from the outside.

\section{Method}

This research focus on, first is determine the effect of individual traditional jump rope games on physical fitness and student motivation. Second, to determine the effect of traditional jump rope games in pairs on physical fitness and student motivation. Third, to 
determine the effect of traditional jump rope games individually and in pairs on physical fitness and student motivation.

The object of the research are first, this research is limited to the influence of traditional jump rope games on physical fitness and student motivation. Second, this study was conducted on futsal MTs extracurricular students. NU Berbek Waru Sidoarjo. Third, the total population as well as the sample of this study were 33 male students in grades 7 and 8 MTs. NU Berbek Waru Sidoarjo whose average age is 13 years.

The purpose of this research is to find out the effect of jump rope games on physical fitness and motivation of extra curricular students in futsal MTs. NU Berbek Waru District Sidoarjo Regency. This research was conducted using a quantitative approach. While the method used in this study is to use a quasi-experimental method, which means that a study is carried out strictly to find out the cause and effect between variables. Among the characteristics of experimental research is that there are treatments (Maksum, 2012: 65). The design or design in this study uses Matching-Only Design (Maksum, 2012: 100) The intended research design can be made as follows table:

Table 1. Research design

\begin{tabular}{|l|l|l|l|}
\hline \multirow{3}{*}{$M$} & $\mathrm{~T} 1_{1}$ & $\mathrm{X}_{1}$ & $\mathrm{~T} 2_{1}$ \\
\cline { 2 - 4 } & $\mathrm{T} 1_{2}$ & $\mathrm{X}_{2}$ & $\mathrm{~T} 2_{2}$ \\
\cline { 2 - 4 } & $\mathrm{T} 1_{3}$ & - & $\mathrm{T} 2_{3}$ \\
\hline
\end{tabular}

\section{Result and Discussion}

In accordance with the formulation of the problem and the purpose of research on the effect of individual jump rope games and group jump rope games on physical fitness and student motivation on extracurricular students in futsal MTs sports. NU Berbek Waru Sidoarjo, where based on the results obtained that, individual jump rope games and jump rope games in groups, the two game methods both have an influence on physical fitness and student motivation, but there are differences in the effect on each variable.

\subsection{Experiment Group Exercise (Individual Jump Rope Game)}

Based on the calculation of the "mean", it is obtained that the average results of physical fitness variables and student motivation after being given the treatment of jump rope games individually increase. After the paired t-test was tested differently the results were significant, so it can be said that the treatment of jump rope games individually has a significant influence on physical fitness and student motivation, which the pattern of this game directs students to keep moving actively with pleasure. These results provide concrete evidence, that jump rope games individually is one form of game that is able to improve students' physical fitness and student motivation. In accordance with what was stated by Rouhi (2017) which states that, playing traditional games can maintain physical health, improve spiritual and mental conditions, and develop cultural values. Constraints that can hinder the effectiveness of guidance in the preparation of students' thesis in the Education Management Masters Program at Unesa Postgraduate Program.Authors and Affiliations. Based on the calculation of the average value of the "mean" data obtained, that the average results of physical fitness variables and student motivation after being given the treatment of 
jump rope games in groups experienced an increase. After the paired t-test was tested differently the results were significant, so it can be said that the treatment of jump rope games in groups has a significant effect on physical fitness and student motivation. These results provide concrete evidence, that jump rope games in groups is one form of game that can improve physical fitness and student motivation. So that indirectly jump rope games in groups also affect the motivation of extracurricular MTs futsal students. NU Berbek Waru Sidoarjo.

\subsection{Experiment Group Exercise II ( Grouo Rope Jump)}

Based on the calculation of the average value of the "mean" data obtained, that the average results of physical fitness variables and student motivation after being given the treatment of jump rope games in groups experienced an increase. After the paired t-test was tested differently the results were significant, so it can be said that the treatment of jump rope games in groups has a significant effect on physical fitness and student motivation. These results provide concrete evidence, that jump rope games in groups is one form of game that can improve physical fitness and student motivation.

So that indirectly jump rope games in groups also affect the motivation of extracurricular MTs futsal students. NU Berbek Waru Sidoarjo.

\subsection{Control Group}

Based on the calculation of the mean value (mean), it was found that the mean results of physical fitness variables and student motivation in the control group, increased, but only very small in futsal MTs extracurricular students. NU Berbek Waru Sidoarjo.

\section{Conclusion}

From the results of data processing and data analysis it can be concluded that, from the process of jump rope games individually and jump rope games in groups gives an influence on physical fitness and student motivation on extracurricular students in futsal MTs futsal sports. NU Berbek Waru Sidoarjo:

(1), jump rope games individually have a significant influence on physical fitness and student motivation. (2), group jump rope games have a significant influence on physical fitness and student motivation. (3) individual jump rope games and group jump rope games have a positive impact or a good effect on the level of physical fitness and student motivation. As for the effect caused by jump rope games individually on physical fitness and student motivation is the level of physical fitness increased by $6 \%$ and the level of student motivation increased by $7 \%$. While the effect caused by jump rope games in groups on physical fitness and student motivation is the level of physical fitness increased by $9 \%$ and the level of student motivation increased by $3 \%$.

\section{References}

World Health Organisation. (2002). Physical Activity and Health. Fifty-fifth World Health Assembly, Document WHA55.23. WHO, Diet, Geneva.

Sadirman. (2006). Interaksi dan Motivasi Belajar Mengajar. Jakarta: PT Raja Grafindo Persada

Mylsidayu. A. (2014). Psikologi Olahraga: Bumi Aksara 
Bastik, C. Et all. (2012). Investigation of basic motor skills according TGMD-2 test on male athletes of 10 ages group who participated to competitions in different sports branches. Social and Behavioral Sciences 46 (2012) 4741-4745.

Vameghi, R. Shams, A. \& Dehkordi, P. S. (2013). The Effect of age, sex and obesity on fundamental motor skills among 4 to 6 years-old Children Pak J Medicine Science. Vol. 2, No. 29. p. 586-589.

Okua, T. Et all. 2013. Physical fitness, physical activity, exercise training and cognitive function in older adults. J Phys Fitness Sports Med, 2(3): 275-286.

Bakar, Ramli. (2014). The Effect of Learning Motivation on Student's Productive Competencies in Vocational High School, West Sumatera. Indonesia: University of Padang. International Journal of Asian Social Science, 2014, 4(6): 722-732.

Maksum, Ali. (2012). Metodologi Penelitian dalam Olahraga. Surabaya: Unesa University Press. 